In Memoriam 


\title{
Klemens von Klemperer (1916-2012): In Memoriam
}

\author{
PieTer M. Judson
}

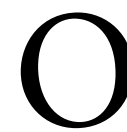

n 23 December 2012, just a few weeks after his 96th birthday, Klemens von Klemperer, the distinguished historian of Central Europe, died. He was born the youngest of four children on 2 November 1916 during World War I, just over two weeks before the death of Emperor-King Francis Joseph, about which fact he frequently enjoyed reminding me. Klemens often related that his very first memory as a toddler was of machine guns across the street, seen from his family's apartment window during the postwar revolutions. His father Herbert was president of the Berliner Maschinenbau-AG, a firm that produced locomotives and submarines for the German military. His grandfather Gustav Klemperer von Klemenau, had converted to Protestantism and served as chair of the Dresdnerbank. His mother Frieda came from the Viennese Kuffner family, brewers of Ottakringer beer. Klemens often spoke of having two Heimats in Central Europe; in different contexts, he felt himself to be both German and Austrian. In Berlin, Klemens attended the prestigious Französisches Gymnasium, from which he graduated in 1934. In that year his father succeeded in gaining a place for him at Balliol College Oxford, but Klemens had other ideas. After spending two weeks there, he ran away to his relatives' home in Vienna, from where he hoped to be able to work against the Nazi regime and where he studied history of law at the University of Vienna.

In his 2009 memoir Voyage through the Twentieth Century: A Historian's Reflections and Recollections (Berghahn), Klemens recounted his dramatic years in 1930s Austria. A close friend of Otto and Fritz Molden, he belonged to a circle of anti-Nazi student activists, most of them Catholics, who sought to realize an older and romantic vision of a federal Central Europe. During and immediately after the Nazi Anschluss of March 1938, Klemens, along with the Moldens (future leaders of the O5 resistance) and other university students, sought actively to organize resistance to the Nazis. For a few months in Austria, he also served as the executor for manuscripts in the estate of Hugo von Hofmannsthal, who was a great uncle by marriage. In November, however, Klemens fled to the United States. By this time, his parents and sister had emigrated to England, and his older brothers had emigrated to the United States. In the United States, Klemens began his study of history at Harvard University, study that was interrupted from 1942-1946 by his service as an intelligence officer in Europe. After the war, he completed his studies at Harvard, obtaining a PhD in history in 1949. He joined the faculty at Smith College (filling a position previously occupied 
by another Central European legend, Hans Kohn), where he became L. Clark Seelye Professor of History in 1979 and a five-college professor in 1990. Besides teaching at Smith College, Klemens was a visiting fellow at Churchill College Cambridge in 1973, a visiting fellow at Trinity College Oxford from 1980-1982, and in 1985 he was a visiting fellow at the Wissenschaftskolleg in Berlin.

At Smith, Klemens also met and married professor of English literature, Elizabeth Gallaher. It was here in Northampton, Massachusetts, and in their idyllic summer cottage at Conway that they raised their children, Catherine and James. It was also here that my siblings and I had the great fortune of getting to know the von Klemperer family, a close friendship that all of us continue to cherish, and that later influenced my own career path decisively. In my high school years, long after I had come to know him as a dear friend, I also had the great fortune to experience Klemens as a teacher at Smith where he introduced us students to the intricacies and compelling narratives of Habsburg history. Much later he also introduced me to his cousin in Vienna, historian Gerald Stourzh.

In 1957, Klemens published his first book, Germany's New Conservatism. Among Austrianists, however, Klemens was best known for an important political biography of Ignaz Seipel, Ignaz Seipel: Christian Statesman in a Time of Crisis (Princeton, 1972). In it he praised Seipel's efforts to win Austrian Catholics and the Christian Social movement for the Austrian Republic after the fall of the monarchy in 1918, referring to the events of November 1918 as a "consensual revolution." At the same time, however, Klemens was more critical of the harsh power politics adopted by Seipel later in the 1920s, policies that he believed had helped increase political polarization in Austria and foreshadowed the crises of the 1930s. In 1988, Klemens participated in the Austrian Academy of Sciences symposium that commemorated the fiftieth anniversary of the Anschluss.

It is for his work on the German resistance to Hitler, however, that Klemens achieved a truly global reputation as scholar and commentator. His many works on those involved in the 22 July 1944 plot, especially Adam Trott zu Solz, constituted an absorbing subject to which he repeatedly returned. In 1988, he published A Noble Combat: The Letters of Sheila Grant Duff and Adam von Trott zu Solz, 1932-1938 (Oxford) and in 1992, German Resistance against Hitler: The Search for Allies Abroad 1938-1945 (Oxford). Among his most important works are also his reflections on Dietrich Bonhoeffer. In 1998, Klemens gave a memorial lecture on Bonhoeffer at the unveiling ceremony for the statues of ten martyrs of the twentieth century in London at Westminster Abbey. Klemens remained a highly productive scholar; at the time of his death, he had completed a new book on the artist Käthe Kolwitz. Until his death, he also continued as an active member in several scholarly networks and as a teacher and mentor to the many younger historians whom he befriended. The many of us who belong to this last category will miss his advice and loyal friendship. 